\title{
Research on Job-Oriented Practical Talents Training Mode -Civil Engineering Major As an Example
}

\author{
Guo Qiu-lan \\ School of Architecture and Planning, Xinyu University, Xinyu, China, 338000
}

Keywords: practical talent training mode; practical teaching; civil engineering

\begin{abstract}
This text begins with the social employment demand on graduates major in civil engineering, elaborates the connotation of cultivation mode of practical talents, and discusses the construction of practical talents training mode system from the perspectives of training objective and training standard, curricular system construction, teaching staff construction, and training program and ways. It emphasizes the importance of practical talents training mode in cultivating civil engineering students' practical ability, and puts forward supporting measures for implementing civil engineering practical talents' training mode from the perspectives of teaching content, practical teaching proportion, and teaching staff.
\end{abstract}

\section{Introduction}

Along with the advancement of urbanization in our country, the social demand for civil engineering graduates is increasing. Civil engineering major graduates may engage in a lot of jobs after graduation, such as managers like construction crew or supervisor in the construction site, counselors engaging in bidding or construction cost, and designers for construction or structure design. Thus students need to improve their overall quality and technical skills, and at the same time have professional practice skill certificates to quickly take up the job role. Therefore, with strong practicality and social application quality, civil engineering major students need to be practically and theoretically dual-energy Practical talents.

\section{The Connotation of Practical Talents Training Mode}

The Concept of Talent Training Mode in Colleges and Universities. "Talent training mode" is the product of higher education teaching reform in our country, which was born in the late 1980's, and developed in the mid 90's.

Gong Yizu expressed the connotation of university talent training mode in "On University Talent Training Mode" that it is some kind of standard structure style and operation mode established in the designing of talent training process with a certain education idea as the essence, higher education talent training activities as ontology or prototype, and revolving around talent training target and it has evident systemic-ness and paradigm. It will take it as the basis in combining with the concrete practice, and takes into account or aims at different objects and conditions to form varied, stylish and featured variants1.

Therefore, college talent training mode can be summarized as talent cultivation is the whole process of " what kind of person" and "how to cultivate" on the basis of certain education thought or education theory in order to cultivate people's knowledge, ability and quality as a goal according to paradigm and systematicness.

Practical talents is relative in terms of academic talents, which emphasizes that a type of specialized talents who can adapt to the actual need of vast employ units as orientation, faces the grass-roots and production line, has a range of complex and comprehensive technologies, and can apply professional knowledge and skills to professional and social practices. Practical talents pay 
attention to the usefulness of knowledge, have innovation spirit and comprehensive ability to use knowledge, and have good ability to deal with instant changes in modern society.

The Qualification of Practical Talents. Practical talents are the talents who transform scientific theory into engineering principle and then convert it to products, who mainly engage in the work which is closely related to social production and living and produces economical benefits.

Based on the graduation whereabouts, civil engineering practical talents can be divided into the following three categories:

(1) Engineering talents. Their main task is to transform the scientific principles found by practical talents into design and planning which can be directly used in social practice, such as civil engineering architecture, and structure designer.

(2) Skilled talents. They are to transform the drawing designed by engineering talents into specific products in the first line in production through actual operation, such as construction crew with construction engineering technology specialty.

(3) Technical talents. They are in the first production line, but they are not specific operators, but are engaging in practice activities like organization and management of production, or service, such us engineering consultant, project manager, etc. majoring in construction project management.

The Meaning of Practical Talents Training Mode. The former deputy minister of education Zhou Yuanqing has made a brief description on the concept of "talent training mode": the so-called talent training mode is actually talents' training target, training specifications and basic training methods.

In his book "Cultivation Modes", Wei Suokang puts forward that talent training mode is the time specification and operating style generally agreed and complied with by a certain education institutions or the community of education workers about talent training activities. With his education purpose as the guide, education method as concrete realization form,it is all elements comprehensive and the whole process comprehensive of education activities which directly effect the body and mind of the instructees based on education content. It reflects a sectional education phenomenon under education mode and above specific teaching methods.

This article regards that talent training mode mainly involves three aspects: one is to cultivate what person namely, training objectives and training specifications; The second is who cultivates, that is professional teacher team construction and curriculum system construction; The third is how to train people, that is training program and training methods.

\section{Civil Engineering Practical Talents Training Mode Construction}

Training Objectives and Training Specifications. Talents cultivation target refers to the "development of various and all kinds talents in achieving the purposes or specifications, which is the talent requirements of certain social politics, economy, productivity and science and technology development." In talent training mode, all reforms are to better realize talents training goal.

To satisfy the needs of talent market characteristics and strengthen civil engineering practical talents education advantages, civil engineering practical talents training goal should be located to develop high quality practical talents with theory, understanding management, and with practical application ability.

From three aspects of knowledge, ability and quality as specifications of civil engineering talents cultivation, students are required to have professional basic knowledge and basic skills of practical application ability to master both "must be enough" professional knowledge and basic skills of 
professional practice in order to have comprehensive professional ability and comprehensive quality. In the process of teaching, efforts should be paid to promote organic integration of knowledge structure, ability structure and quality structure in order to better achieve the cultivation of practical talents and improve the students' employment competitiveness.

In the aspect of knowledge structure, wide foundation, profound specialized direction, specialty creating and specialty patterns are required, and in other basic work process like curriculum and teaching material construction, basic knowledge and practical application are emphasized, and relatively focus on cutting-edge knowledge acquisition in the field of unknown. On the ability structure, students are required to have outstanding innovation ability, comprehensive application ability and practice ability, and strong communication ability, cooperation ability and self-study ability. In the aspect of quality structure, students are required to learn knowledge, interpersonal skills, solidarity and cooperation, survival and development ability. From the three aspects, the training of civil engineering practical talents should pay more attention to ability and quality training and cultivation.

Construction of Curriculum System. Taking market as guidance, sticking to talent training goal, and performing curriculum system optimization, emphasis should be paid on practice teaching system and platform construction to construct practical teaching system and increase the proportion of practice teaching. The cumulative credit of civil engineering specialized practice teaching should be not less than $25 \%$ of the total credits to highlight the practical teaching link and improve the quality of civil engineering practice teaching. To strengthen the practice teaching, first, let students have more practice time while increasing the proportion of experimental ability and practical ability. Let the students fully realize the importance of practical ability, arouse their learning enthusiasm. Incentive mechanism must be taken to encourage and urge teachers to practice teaching mode reform and innovation to make their teaching mode beneficial to the development of college students' innovative practice ability.

According to the practical talents cultivation standard, practice teaching content system is built which composing three modules as basic ability training, professional course practice teaching, and development and innovation.

In basic professional ability training mode, set the general demand platform to require students to master basic general knowledge of civil engineering, such as: building surveying, building materials, construction mechanics, building codes, building structure, etc., and make them clear in the teaching plan.

In development and innovation of the mode, take subject competitions and college students' innovative ability training as the purpose in order to promote learning, unite teaching and competition, set up teaching reform, and require putting extracurricular technological innovation activities into the practical teaching system for unified organization and management, and establish well arranged, system specification, practical, solid and effective college students science and technology innovation training system. So that extracurricular activities and classroom teaching could echo each other with mutual penetration, mutual promotion, stimulate students' interest in learning, improve the students' practical ability and innovation ability, and guide each student to take an active part.

In professional course practice mode, it includes course experiment, professional practice, professional design (paper) and so on three aspects. In experiment courses, laboratory construction should be strengthened and laboratory construction should have overall planning. According to the feature, set laboratory. The same laboratory can undertake experimental teaching tasks with different professions and different courses, and at the same time gradually reduce the verification and demonstration experiments, increase design-ability, comprehensiveness and innovative experiments so as to improve the use efficiency; In professional practice, strengthen practice teaching base 
construction, intensify campus practice teaching base construction, construct a number of practice base which provide direct services to students practice ability training, and meanwhile set up high-quality off-campus practice base in order to meet the need of practical talents training; In professional design (paper), take entities project or simulating actual project environment as the background, aim at a certain subject, do comprehensive and innovative curriculum design, graduate design, and try to increase design topics to strengthen students' employment. Student and teacher's two-way choice is adopted. Let the students feel actual combat simulation of work environment before graduation, and shorten the students adaptative phase while entering society.

Teacher Team Construction. Practical undergraduate teachers have the main characteristic of "double qualification type". To build practice teacher team with a sufficient number, reasonable structure, and strong practice ability, it is the key to complete practical undergraduate practical teaching content.

Teachers are in a dominant position in education teaching activities, and each link of teaching activities directly contacts with the teacher. At the same time, the teacher is also practical talents training quality guarantee. So "double qualification type" teachers team construction is the key to the implementation of practical talents training. This requires that teachers must first have a strong sense of practice, next have abundant practical teaching experience and strong ability of practice teaching. Universities should encourage teachers with high education and high professional title to do practice teaching. While emphasizing high professional titles and high education, teachers' practical ability should be paid more attention to. Teachers must first walk into the laboratory, improve their practical operating ability, and the school should also pay special attention to the "double qualification type" teacher training work, and provide ample opportunity to enhance teachers' practice ability.

Increase the introduction of "double qualification type" teachers. "Double qualification type" teachers are indispensable software security in the construction of application-oriented talent construction. Part of the teachers may be got from other colleges and universities, scientific research institutions and enterprises and institutions to strengthen the construction of applied talent training policy with their rich teaching experience and practice experience.

Strengthen the cultivation of young teachers "double qualification type" quality. For young teachers' weakness as lacking of practical experience, hire some technical talent on a regular basis from enterprises and institutions to to do some practical ability display and speech, and communicate with school teachers. Combine theory teaching and practice teaching, emphasize the industry-university-institute cooperation, and establish teachers' practice bases. Raise the level of teachers' scientific research and engineering practice ability through resource sharing with cooperation units and talent mutual employment to improve teachers' scientific research ability and engineering practice ability, and achieve a win-win situation with enterprises.

Strengthen "double qualification type" teacher evaluation system. Establish the corresponding rewards and punishment mechanism, such as setting up the "double qualification type" teachers allowance. In the promotion title, research funding, teaching appraisal, whether to have the "double qualification type" quality as one of the necessary main conditions, give full play to their enthusiasm, speed up the pace of construction progress of "double qualification type" teachers team.

Training Plan And Training Methods. On the teaching contents and curriculum system, take professional ability and quality education as the main line, and determine the teaching content and curriculum system accordingly. In order to meet the need of various technical application ability and professional skills, the course system form tends to form a modular structure. In teaching process and methods, different from cultivating theory research talent, the teaching process adopts the way of theory and practice interactive teaching process, which requires cooperation way to train higher practical talents with implementation of learning, production and research, combining schools with 
industries, departments or units. In the process of practice, not only can students' operation skill be cultivated, but also it can cultivate students' professional ethics and interpersonal skills. Professional teachers are required to have high level of business and technology application ability and practice ability. The overall teaching staff have the characteristic of "double qualification type". At the same time, enterprises and social experts are hired to be teachers to spread new knowledge, new technology, new procedure and practical experience to the school, and students.

\section{The Safeguard Measures of Civil Engineering Practical Talents Training Mode Implementation}

The Teaching Contents Are Not Fixed. Based on the characteristics of practical talents, the teaching content should be the unity of the flexibility, targeted and vocational adaptability. Professional class should not have fixed materials. If a fixed teaching material is selected, it should only be reference of the lecturer. The real teaching content should be according to the needs of society and enterprise actual work needs. This requires schools continuously update the teaching contents according to the development of society, industry and enterprise needs. At the same time, guarantee the vocational adaptability of teaching content, namely on the basis of target, appropriately broaden the marketability, strengthen basic teaching contents, and make the graduates be competent for a wider range of jobs.

Proportion of Practice Teaching Is Not Reduced. According to market demand for civil engineering graduates, "skillful craftsman college graduates" are basically required. Practical talents with strong professional practice skill must be trained with the quality of "be on the ground, retainable, useful, good work". So practice teaching is an indispensable part of civil engineering, and is also the key of our practical talents training.

Practice teaching link includes professional course's experiment teaching (material test, experiment in mechanics, structural test, etc.), professional practice (practice cognition, produce practice, field work, etc.), all kinds of professional practice (centralized measurement practice, construction technology training, etc.), professional design (curriculum design, graduation design, etc.) and so on three aspects.

In order to guarantee the opening of practice teaching, we should have a well equipped laboratory construction, campus and off-campus practice teaching base construction, and the corresponding "double qualification type" teaching staff to ensure the practice teaching course opening, and guarantee the school's teaching quality of practical talents training.

Teachers Staff Is Stable. "Double qualification type" teaching staff is indispensable software security in the construction of practical talents. It requires that it not only have the "double qualification type" teachers, but a more stable "double qualification type" teachers. Make use of their technology development and technology application ability, combine theoretical knowledge so as to provide teacher staff guarantee cultivate high-level practical talents.

In order to ensure the stable "double qualification type" teachers, young teachers "double qualification type" quality may be cultivated, and outstanding "double qualification type" teachers may be introduced from other colleges and universities, scientific research institutions and enterprises and institutions and a long term cooperation outside "double qualification type" teachers may be built.

\section{References}


[1] Huang Bin. Depth interpretation of the connotation of higher vocational college "double qualification type" teachers [[J]. Journal of Education and Profession, 2006, 11:36-38.

[2] He Hui. The co-operative study of undergraduate course level technical talent training [[D]. Chinese Management Informatization, 2012, 4:107-108.

[3] Wu Junmei. An effectiveness research of local higher vocational colleges "double qualification type" teachers cultivating [J]. Journal of Economic and Technology Cooperation Information, 2010, 9.

[4] Zhao Shiping. The reform thought of civil engineering professional practice teaching [J]. Journal of Hainan University, 2001, 9:301-304.

[5] Yang Wangcai. The reform exploration of higher vocational civil engineering talents training scheme [J]. Construction of Vocational Education, 2008, 1:29-31.

[6] Liu XiaoPing etc. Build competence-based "architectural engineering technology" specialized talent training plan and course system [J]. China's Construction of Education, 2007, 8:7-8.

[7] Han Jianqiang etc. Professional teaching reform aiming in training practical talents [J]. Authority, 2012, 4:98-99.

[8] Zhou Li. The research and practice of civil engineering professional practice teaching system [J]. Journal of Higher Education Research in Hei Longjiang Province, 2005, 1:156-157.

[9] Cao Bangqing. Practice teaching system construction of civil engineering professional skilled talent training [J]. Journal of Nanyang Normal University, 2009, 3:116-117.

[10] Zhou Hui. The status quo of Practical talents training mode research in newly built undergraduate colleges and universities [D]. Master Thesis of Nan Chang university, 2010. 